\title{
Effect of L-glutamine and n-butyrate on the restitution of rat colonic mucosa after acid induced injury
}

W Scheppach, G Dusel, T Kuhn, C Loges, H Karch, H-P Bartram, F Richter, S U Christl, H Kasper

mucosa and, by unknown mechanisms, stimulate cell proliferation within colonic crypts. ${ }^{56}$

Glutamine and butyrate may be important in supporting epithelial repair mechanisms occurring in several forms of inflammatory bowel disease. ${ }^{7}$ Based on this assumption both substrates have been used empirically to treat patients with pouchitis (glutamine) ${ }^{8}$ or ulcerative colitis (butyrate).$^{910}$ To study epithelial injury and repair in experimental colitis, several noxious agents have been used including deoxycholate, ${ }^{11}$ alcohol, ${ }^{12}$ formaldehyde, ${ }^{13}$ acetic acid, ${ }^{14}$ and hydrochloric acid. ${ }^{15}$ While these models do not reflect all aspects of human colonic disease, they do provide information about mechanisms whereby the colonic epithelium can recover from injury.

When isolated colonic mucosa placed in the Ussing chamber is incubated with luminal $\mathrm{HCl}$ the superficial epithelium is desquamated whereas the crypts are left intact. Electronmicroscopic studies show that epithelial resealing occurs within several hours, probably as a result of cell migration from the crypts to the flat luminal mucosa. ${ }^{15}$ In this study the hypothesis was tested that colonic nutrients (glutamine, butyrate) may accelerate recovery after acid induced injury. of rat colo sule This effect on the gut barrier is associated with a stimulation of crypt cell proliferation. The addition of glutamine to parenteral solutions may be beneficial for patients under intensive care whose intestinal barrier is weakened in the course of sepsis and trauma.

(Gut 1996; 38: 878-885)

Departments of Medicine W Scheppach G Dusel T Kuhn C Loges H-P Bartram

F Richter S U Christl H Kasper

and Microbiology $\mathrm{H}$ Karch

University of Wurzburg, Wurzburg, Germany

Correspondence to: Dr W Scheppach, Department of Medicine University of Wurzburg, Josef-Schneider-Strasse 2, D-97080 Wurzburg, Germany.

Accepted for publication 28 December 1995
Keywords: glutamine, butyrate, mucosal repair, colon, Ussing chamber.

In the postprandial state, the colonic mucosa receives its nutrients preferentially from the luminal side and not, as previously assumed, from the vascular side. ${ }^{1}$ After a few days of oral starvation mucosal atrophy develops, ${ }^{2}$ probably because of the inability of the vasculature to supply fully the energy needs of the epithelium. An alternative explanation for the finding would be a reduced workload of this tissue (reduced absorption and secretion) in the absence of luminal contents. ${ }^{3}$ The preferred epithelial nutrients are glutamine in the proximal and n-butyrate in the distal colon, ${ }^{4}$ the second of these being produced by bacteria as an end product of carbohydrate fermentation. These substrates provide energy to the

\section{Methods}

\section{Preparation of distal colon}

Male Wistar rats (250-300 g, Wiga, Sulzfeld, Germany) were fed standard rat chow and water ad libitum before the experiments. Rats were killed by cervical dislocation and, after midline incision, the colon was removed and rinsed clear of its luminal contents with ice cold saline. Before use, tissues were maintained in ice cold saline bubbled with carbogen gas (95\% oxygen, 5\% carbon dioxide). Within 15 minutes, the serosal and muscular layers were removed by placing the sheet of distal colon, serosal side up, on a rubber plate moistened with ice cold saline. A transverse incision was made with a razor blade through the muscular layer, and the outer layers were gently removed from the mucosa/submucosa with a fine curved forceps. Histological examination showed that a pure mucosal/submucosal preparation of rat colon was obtained (Fig 1). ${ }^{16-18}$

\section{Ussing chambers and solutions}

Pieces of the mucosa/submucosa preparation were mounted in Ussing chambers exposing 
$0.785 \mathrm{~cm}^{2}$ of tissue surface area to $4 \mathrm{ml}$ of appropriate solutions. Control and experimental tissues were always obtained from the same animal and incubated simultaneously. The following solution was used on the serosal and luminal sides of the mucosa: $\mathrm{Na}^{+} 145 \mathrm{mmol} / \mathrm{l}$, $\mathrm{K}^{+} 5 \mathrm{mmol} / \mathrm{h}, \mathrm{Ca}^{++} 1.2 \mathrm{mmol} / 1, \mathrm{Mg}^{++} 1.2$ $\mathrm{mmol} / \mathrm{l}, \mathrm{Cl}^{-} 124.8 \mathrm{mmol} / 1, \mathrm{HCO}_{3}{ }^{-} 25 \mathrm{mmol} / 1$, $\mathrm{PO}_{4}{ }^{-}-4.2 \mathrm{mmol} / \mathrm{l}$. On the luminal side, mannitol $(5 \mathrm{mmol} / \mathrm{l})$ and lactulose $(5 \mathrm{mmol} / \mathrm{l})$ were added to the electrolyte solution for permeability measurements; this osmotic load to the luminal side was balanced by adding xylose $(10 \mathrm{mmol} / \mathrm{l})$ to the serosal side. The $\mathrm{pH}$ value of both solutions was 7.55. The chambers were circulated by carbogen gas lift and kept at $37^{\circ} \mathrm{C}$ in water-jacketed reservoirs. The chemicals were purchased from Sigma (St Louis, MO). It has been shown previously ${ }^{15}$ that stripped colonic mucosa bathed in a nutrient free solution can be kept viable for five hours.

\section{Electrical measurements}

Transepithelial potential difference (PD) was measured using matched calomel reference electrodes (Ref 401, Radiometer, Copenhagen, Denmark) connected to a high impedence potentiometer (Qualitron, Haarlem, the Netherlands) and immersed in saturated $\mathrm{KCl}$; the electrical apparatus was connected to the chambers through salt-agar bridges. Every five minutes, 5 uA current pulses were applied to chambers through platinum electrodes. The change in PD was recorded and the tissue conductance $\left(\mathrm{mS} / \mathrm{cm}^{2}\right)$ calculated by Ohm's law. Parallel experiments were considered comparable if the conductance of paired tissues differed by less than $25 \%$ in the initial equilibration period.

When a stable tissue conductance had been established (usually within 30 minutes), chemical injury was induced by replacing the luminal solution with $\mathrm{HCl}(15 \mathrm{mmol} / \mathrm{l})$ for five minutes. As shown by other authors, this intervention leads to reversible tissue damage (loss of the superficial epithelium, resealing by cell migration from the colonic crypts). ${ }^{15}$ Afterwards, fresh incubation medium (composition as already described) was filled in the chambers and $\mathrm{PD} /$ conductance were measured for four hours after tissue injury. The media bathing the serosal and mucosal sides of the mucosa were changed every hour and aliquots frozen at $-20^{\circ} \mathrm{C}$ for subsequent analysis of mannitol, lactulose, and xylose (within three months).

\section{Interventions}

In the initial validation experiment, the effect of tissue injury was assessed by adding $\mathrm{HCl}$ ( $15 \mathrm{mmol} / \mathrm{l}$, five minutes) to the luminal side of one Ussing chamber and inducing no injury to the other chamber $(n=6)$. Neither butyrate nor glutamine were used in this experiment.

In further experimental series, chemical injury was induced to both chambers, and the effect of colonic nutrients (glutamine, butyrate) on mucosal resealing was compared with control conditions (equimolar $\mathrm{NaCl}$ added instead of glutamine/butyrate):

(1) L-glutamine (2 mmol/l), added to the serosal and luminal sides after tissue injury with $\mathrm{HCl}(\mathrm{n}=6)$.

(2) L-glutamine ( $2 \mathrm{mmol} / \mathrm{l})$, added only to the serosal side after tissue injury with $\mathrm{HCl}$ $(n=7)$.

(3) n-butyrate (10 $\mathrm{mmol} / \mathrm{l})$, added to the luminal side after tissue injury with $\mathrm{HCl}$ $(n=6)$.

(4) n-butyrate $(10 \mathrm{mmol} / \mathrm{/})$, added to the luminal side before and after tissue injury with $\mathrm{HCl}$ (preincubation period of one hour) $(n=7)$.

\section{Analysis of mannitol and lactulose}

The tissue permeability for mannitol/lactulose (luminal to serosal side) was assessed by measuring hourly the concentrations in the incubation media by gas-liquid chromatography. ${ }^{19}$ To $200 \mu$ l of the incubation medium (contained in disposable injection vials) 250 nmol phenyl- $\beta$-D-glucopyranoside was pipetted as internal standard and taken to dryness under nitrogen in a heating block at $75^{\circ} \mathrm{C}$. Subsequently, $100 \mu$ l oxime solution $(25 \mathrm{mg}$ of hydroxylamine hydrochloride per $\mathrm{ml}$ of pyridine) was added and the glass vial capped; the sugars were converted to oximes during the following incubation period of 30 minutes at $75^{\circ} \mathrm{C}$. After allowing the samples to cool, $100 \mu \mathrm{l}$ of $\mathrm{n}$-trimethylsilyl imidazole reagent was added and the solution incubated for 15 minutes at $75^{\circ} \mathrm{C}$. The silylation reagent was bought from Macherey-Nagel (Düren, Germany) and all other chemicals from Sigma (St Louis, MO).

A stock solution containing mannitol $(5 \mathrm{mmol} / \mathrm{l})$ and lactulose $(5 \mathrm{mmol} / \mathrm{l})$ was prepared in deionised water. From this solution, $0 / 10 / 25 / 50 \mu \mathrm{l}$ were pipetted into glass injection vials to which $250 \mathrm{nmol}$ internal standard were added. The conversion to oximes and subsequent silylation was performed as described before. Thus, a standard curve was set up under the same conditions as the unknown samples were analysed.

One $\mu l$ of derivatised sample was injected into a DB- 5 capillary column $(15 \mathrm{~m} \times 0.53 \mathrm{~mm}$ ID, J and W Scientific, Folsom, CA) installed on a HP 5890 A gas chromatograph (HewlettPackard, Palo Alto, CA). The chromatographic conditions were as follows:

(1) Gas: helium at a column flow rate of 5 $\mathrm{ml} / \mathrm{min}$, make up gas $25 \mathrm{ml} / \mathrm{min}$, splitless injection.

(2) Temperatures: injection port $220^{\circ} \mathrm{C}$, flame ionisation detector $300^{\circ} \mathrm{C}$, oven temperature programme: $150^{\circ} \mathrm{C}$ for $0 \mathrm{~min}$, ramp $15^{\circ} \mathrm{C} / \mathrm{min}$ to $300^{\circ} \mathrm{C}$ (kept for $5 \mathrm{~min}$ ).

The computerised data analysis made use of an HP 3365 Chemstation (Hewlett-Packard, Palo Alto, CA).

Bacterial strains and bacterial tissue permeation The $E$ coli strain 11-1 (serotype O111: $\mathrm{H}^{-}$) was 
used for the permeation studies. This strain is resistant to ampicillin and shows localised adherence to HEp-2 cells. ${ }^{20}$ In addition, strain 11-1 possesses the $90 \mathrm{~Kb}$ virulence plasmid and does not produce verotoxins or heat labile or heat stable enterotoxins. ${ }^{20}$

$E$ coli $\mathrm{O} 111$ cells were grown overnight in Luria broth and centrifuged. The pellet was suspended in the electrolyte solution used for Ussing chamber experiments (composition as before) to obtain $2 \times 10^{7}$ colony forming units (Cfu) per ml. This suspension was added to the luminal half chambers in the fourth hour after tissue injury. The permeation across the mucosal sheet was assessed by measuring the density in the serosal half chambers after 60 minute exposure. From $1 \mathrm{ml}$ of this suspension $100 \mu \mathrm{l}$ underwent serial 10 -fold dilution $\left(10^{5}\right.$ to $\left.10^{2}\right)$ and were spread on MacConkey agar plates containing $100 \mu \mathrm{g} / \mathrm{ml}$ ampicillin. Colonies were serogrouped by slide agglutination test with $E$ coli $\mathrm{O} 111$ antiserum (Behringwerke, Marburg, Germany) and by polymerase chain reaction as described..$^{20}$

\section{Colonic crypt proliferation}

In the fourth hour after tissue injury $0.8 \mu \mathrm{mol}$ bromodeoxyuridine (BrdU) was added both to the luminal and serosal side of the tissue to label proliferating cells within colonic crypts immunohistochemically. Details of this method have been described previously. ${ }^{621}$ In brief, mucosal sheets were fixed in ethanol $(95 \%, v / v)$ for 12 hours and embedded in Paraplast (Monoject Scientific, Athy, Ireland). The specimens were section cut into $2 \mu \mathrm{m}$ slices using a Leitz microtome (Leitz, Wetzlar, Germany). Denaturation of DNA was achieved by incubation ( $30 \mathrm{~min}$ ) with $2 \mathrm{~N}$ $\mathrm{HCl}$. Mouse anti-BrdUrd monoclonal antibody (no 7580, Becton-Dickinson, San Jose, CA) was applied (1:100 dilution, one hour incubation), followed by biotinylated antimouse immunoglobulin (1:100 dilution, 30 minute incubation, RPN 1001, Amersham, Buckinghamshire, UK) as second antibody. After 30 minute incubation with biotinylated streptavidin (1:100 dilution, RPN 1051, Amersham), BrdUrd-labelled cells were visualised using diaminobenzidine solution $(0.5$ $\mathrm{g} / \mathrm{l}$, Serva, Heidelberg, Germany) with $0.15 \mathrm{~g} / 1$ $\mathrm{NiCl}_{2}$ and $0 \cdot 15 \mathrm{~g} / 1 \mathrm{CoCl}_{2}$ as intensifiers. All reactions were performed at room temperature unless otherwise specified. Finally, the specimens were counterstained with nuclear fast red.

The histological slides were viewed under a Laborlux S microscope (Leitz) at a 625fold magnification. In every case, proliferation of colonic crypt cells was evaluated by counting the number of BrdUrd-labelled cells and the total number of cells in 40 longitudinally sectioned crypt columns according to the criteria described by Lipkin et al. ${ }^{22} \mathrm{An}$ average labelling index (LI) per individual crypt was calculated from the number of labelled cells divided by the total number of cells.

\section{Statistics}

Values are given as mean (SEM). Areas under curve (AUC) were calculated using the trapezoidal rule. Significant differences $(p<0.05)$ between interventions were calculated by Wilcoxon's rank sum test for paired data. The statistical software package NCSS (Unisoft, Augsburg, Germany) was used for data analysis.

\section{Results}

Validation experiment $(\mathrm{n}=6)$

The model of acid induced injury of stripped rat mucosa maintained in Ussing chambers has been used by Argenzio et al ${ }^{1114}$ and Feil et $a l .{ }^{15}$ Based on this previous work we confirmed that a fresh preparation of distal rat mucosa/submucosa stripped of the underlying muscular layer can be kept viable for five hours (histological appearance, maintenance of potential difference, and conductance).

Histological tissue damage was most noticeable one hour after luminal acid exposure (Fig 1A): luminal $\mathrm{HCl}$ (15 mmol/1, $5 \mathrm{~min}$ ) caused uniform mucosal damage characterised by exfoliation of the superficial epithelial layer and denudation of the lamina propria. In contrast, the crypts did not show any histological evidence of damage. Tissue resealing was seen four hours after acid exposure, probably as a result of cell migration from the intact crypts (Fig 1B).

When rat distal colonic mucosa was incubated with $\mathrm{HCl}$ in chamber A while no acid injury was induced in chamber $B$ the following data were obtained: after $\mathrm{HCl}$ injury the potential difference (PD) dropped significantly

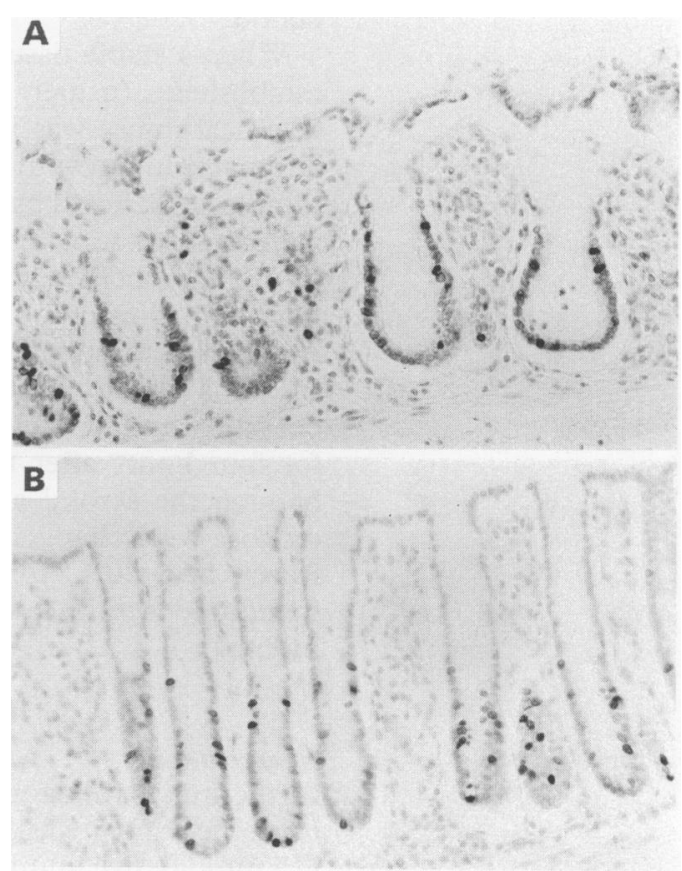

Figure 1: Histological appearance of stripped mucosa after luminal $\mathrm{HCl}$ exposure (magnification, $\times 300)$. (A) Thirty minutes after injury. Desequamation of the superficial epithelial layer and denudation of the lamina propria; crypt structure intact; S-phase labelling with BrdU (dark cells). (B) Four hours after injury. Epithelial resealing occurring in the flat mucosa; S-phase labelling with BrdU (dark cells). 
$(\mathrm{p}<0.05)$ from $4.4(0.8) \mathrm{mV}$ to $1.2(0.2) \mathrm{mV}$ (1 hour) and rose gradually to $2 \cdot 7(0 \cdot 8) \mathrm{mV}(4$ hours). In the control experiment no significant decrease of PD was obtained. PD was significantly $(p<0.05)$ lower one and two hours after $\mathrm{HCl}$ administration than under control conditions.

The conductivity (C) rose significantly $(\mathrm{p}<0.05)$ from $8.4(0.8)$ to $19.3(4.5) \mathrm{mS} / \mathrm{cm}^{2}$ (1 hour) after $\mathrm{HCl}$, followed by a decline to

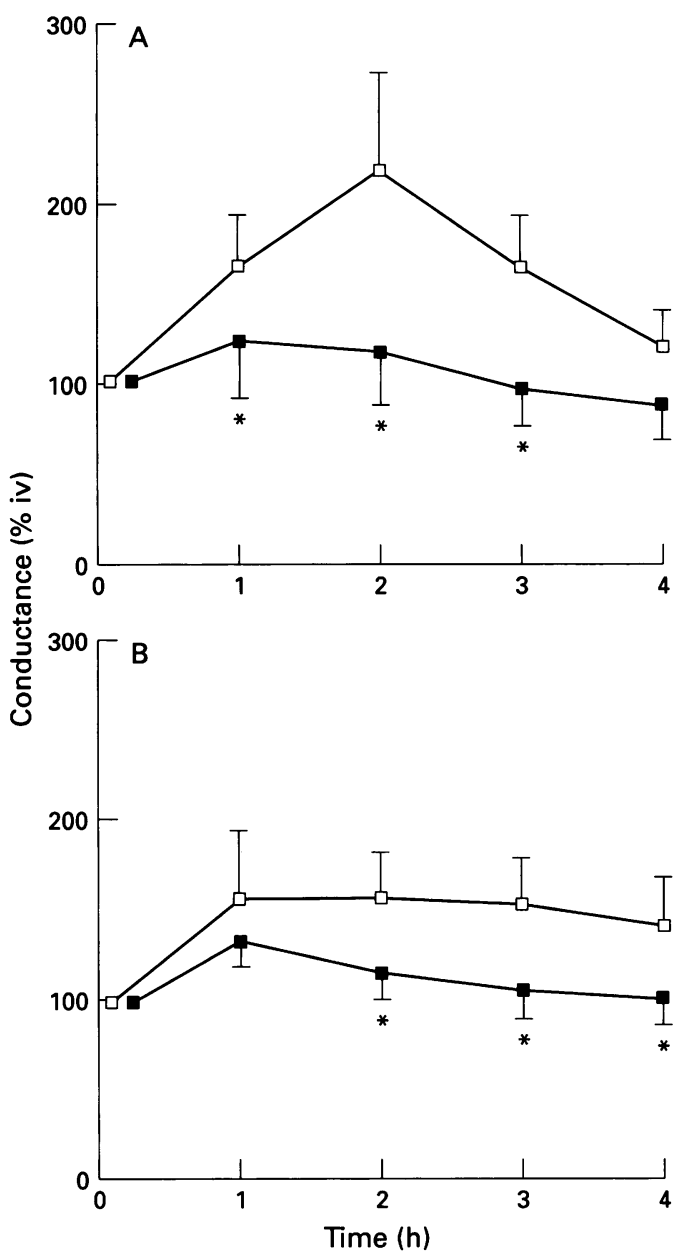

Figure 2: Effect of L-glutamine on tissue conductance after $\mathrm{HCl}$ exposure (zero hour denotes the time after removal of $\mathrm{HCl}$ but before addition of glutamine). (A) L-glutamine ( $2 \mathrm{mmol} / \mathrm{l})$ added to the serosal and mucosal sides of the mucosa. (B) L-glutamine (2 mmoll) added to the serosal side of the mucosa. (Filled symbols: L-glutamine incubation, open symbols: control experiment; \% iv=per cent of initial value at 0 hours; ${ }^{\star}$ shows significant differences with $p<0 \cdot 05$ ).

TABLE I Effect of L-glutamine on colonic mucosa after HCl induced injury

\begin{tabular}{|c|c|c|c|}
\hline & Glutamine & $\mathrm{NaCl}$ (control) & p Value \\
\hline \multicolumn{4}{|c|}{ (A) Effect of L-glutamine $(2 \mathrm{mmol} /)(n=6)$ added to the serosal and mucosal sides of the mucosa } \\
\hline Potential difference (AUC: $\%$ iv $\times$ h) & $278 \cdot 8+88 \cdot 6$ & $194 \cdot 5+46 \cdot 8$ & $0 \cdot 110$ \\
\hline Conductance (AUC: $\%$ iv $\times$ h) & $420 \cdot 4+81 \cdot 9$ & $642 \cdot 6+101 \cdot 5$ & 0.028 \\
\hline Mannitol $_{\mathrm{s}}$ (AUC: $\mu \mathrm{mol} / / \times \mathrm{h}$ ) & $42 \cdot 5+8 \cdot 7$ & $146 \cdot 5+33 \cdot 2$ & $0 \cdot 028$ \\
\hline Lactulose $_{\mathrm{s}}$ (AUC: $\mu \mathrm{mol} / 1 \times \mathrm{h}$ ) & $35 \cdot 8+5 \cdot 1$ & $87 \cdot 0+19 \cdot 5$ & 0.028 \\
\hline $\mathrm{EPEC}_{\mathrm{s}}$ (cfu/ml) $4 \mathrm{~h}$ & $2022+1029$ & $33700+13026$ & $0 \cdot 028$ \\
\hline Mucosal cell proliferation: total & $0 \cdot 19+0 \cdot 01$ & $0 \cdot 14+0 \cdot 01$ & 0.043 \\
\hline \multicolumn{4}{|c|}{ (B) Effect of L-glutamine $(2 \mathrm{mmol} / \mathrm{l})(n=7)$ added to the serosal side of the mucosa } \\
\hline Potential difference (AUC: $\%$ iv $\times h$ ) & $250 \cdot 9+32 \cdot 0$ & $134 \cdot 0+18 \cdot 6$ & 0.028 \\
\hline Conductance (AUC: $\%$ iv $\times h$ ) & $462 \cdot 3+18 \cdot 5$ & $569 \cdot 0+35 \cdot 0$ & 0.028 \\
\hline Mannitol $_{\mathrm{s}}$ (AUC: $\mu \mathrm{mol} / / \times \mathrm{h}$ ) & $154 \cdot 8+19 \cdot 7$ & $238 \cdot 8+22 \cdot 3$ & 0.046 \\
\hline Lactulose $_{\mathrm{s}}$ (AUC: $\mu \mathrm{mol} / \mathrm{l} \times \mathrm{h}$ ) & $83 \cdot 6+21 \cdot 1$ & $109 \cdot 9+20 \cdot 3$ & NS \\
\hline $\mathrm{EPEC}_{\mathrm{s}}(\mathrm{cfu} / \mathrm{ml})$ & $12646+8383$ & $71743+59976$ & NS \\
\hline \multicolumn{4}{|l|}{ Mucosal cell proliferation: total } \\
\hline crypt labelling index $\quad 4 \mathrm{~h}$ & $0 \cdot 15+0 \cdot 01$ & $0 \cdot 10+0 \cdot 01$ & 0.036 \\
\hline
\end{tabular}

$\%$ iv = per cent of initial value at 0 hours; $\mathrm{AUC}=$ area under curve; $\mathrm{EPEC}_{\mathrm{s}}=$ enteropathogenic $E$ coli recovered on the serosal side of the mucosa; $c f u=$ colony forming unit; NS=not significant.
$14.5(5 \cdot 1) \mathrm{mS} / \mathrm{cm}^{2}$. In the control run, no increase in $\mathrm{C}$ was noted (mean values between $7 \cdot 0$ and $8 \cdot 1 \mathrm{mS} / \mathrm{cm}^{2}$ ). C showed a significant $(\mathrm{p}<0.03)$ difference between $\mathrm{HCl}$ and control at one, two, and three hours.

Markers of mucosal permeability (mannitol, lactulose) were added to the mucosal chamber ( $5 \mathrm{mmol} / \mathrm{l}$ each) and the serosal concentration measured hourly. At one and two hours, the serosal mannitol concentrations were significantly $(\mathrm{p}<0.05)$ higher after $\mathrm{HCl}$ administration than in the control run (one hour: $22.3(2.5)$ $v 11.0(1.4) \mu \mathrm{mol} / 1$; two hours: $23.1(3.0)$ $v 16.2(2.0) \mu \mathrm{mol} / \mathrm{l})$. The same difference between $\mathrm{HCl}$ and control was obtained for lactulose (one hour: 12.9 (1.8) v 5.5 (1.1) $\mu \mathrm{mol} / /$; two hours: $14.4(4.2)$ v $6.8(0.8) \mu \mathrm{mol} /$, $\mathrm{p}<0.05$ ).

In the fourth hour of incubation, the permeation of the enteropathogenic strain 11-1 of $E$ coli $\mathrm{O} 111: \mathrm{H}^{-}$(EPEC) from the luminal $\left(2 \times 10^{7} \mathrm{cfu} / \mathrm{ml}\right)$ to the serosal chamber was assessed. The serosal EPEC density was significantly higher with $\mathrm{HCl}$ induced injury (13675 (5479) cfu/ml) than without $\mathrm{HCl}$ (1258 (668) cfu/ml, $\mathrm{p}<0 \cdot 05)$.

Cell proliferation within colonic crypts was unaffected by $\mathrm{HCl}$ administration: the total crypt labelling index (LI) after $\mathrm{HCl}(0.16$ $(0.02))$ was not different from LI under control conditions $(0 \cdot 14(0 \cdot 01), \mathrm{NS})$. This provides further evidence of the superficial nature of acid induced mucosal damage.

It was concluded from these data that $\mathrm{HCl}$ at the appropriate concentration and exposure time caused reversible injury to the distal colon of rat. A potential modifying effect of colonic epithelial nutrients (L-glutamine, n-butyrate) was investigated in the following experiments.

\section{Glutamine experiments}

The effects of L-glutamine $(2 \mathrm{mmol} / \mathrm{l})$ added to the serosal and mucosal side $(n=6)$ are summarised in Figure 2A and Table IA. A trend ( $p$ values given in Figures and Tables) towards a higher PD in the presence of L-glutamine was found, compared with control conditions (Table IA). As the conductance is considered a valuable marker for epithelial integrity ${ }^{23}$ these data are presented in detail (Fig 2A). As a sign of mucosal leakage tissue conductance increased significantly in the control experiment, reaching its highest values two hours after $\mathrm{HCl}$ incubation $(216 \%$ of the initial value at 0 hours). Thereafter conductance values declined to $120 \%$ of the initial value, indicating mucosal resealing. In the L-glutamine experiment a significant rise of conductance did not occur; it differed significantly between L-glutamine and control at one, two, and three hours. L-glutamine (serosal + mucosal) also caused a diminished permeability for mannitol and lactulose (Table IA). The permeation of EPEC at four hours was significantly decreased in the presence of L-glutamine. L-glutamine stimulated mucosal cell proliferation, raising significantly the total crypt labelling index in the fourth hour of incubation. 
Similar data were obtained when L-glutamine $(2 \mathrm{mmol} / \mathrm{l})$ was added only to the serosal side $(n=7)$ of the chamber (Fig $2 B$, Table IB). The PD was significantly higher in the presence of L-glutamine than in its absence (Table IB). The conductance (Fig 2B) increased significantly in the control experiment at one hour and remained increased throughout. Also in the

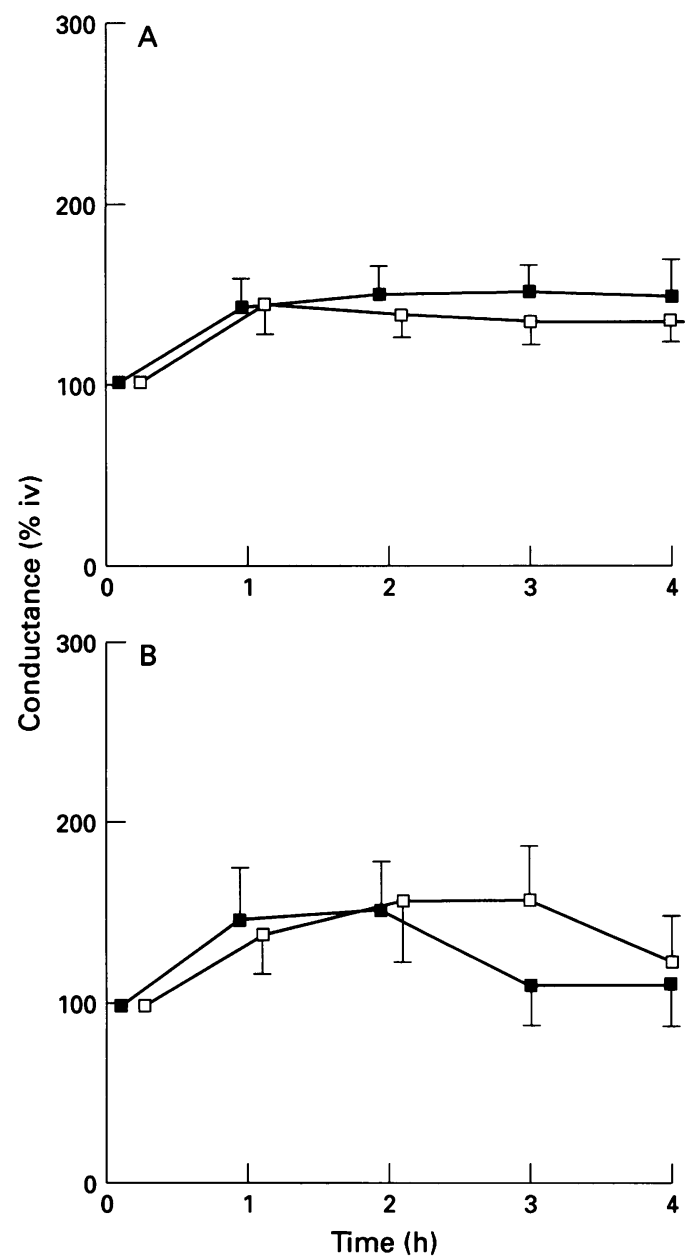

Figure 3: Effect of n-butyrate on tissue conductance after $\mathrm{HCl}$ exposure (zero hour denotes the time after removal of $\mathrm{HCl}$ but before addition of butyrate). (A) Butyrate (20 mmoll) added to the luminal side of the mucosa without a preincubation period. (B) Butyrate (20 mmoll) added to the luminal side of the mucosa with a preincubation period (one hour before $\mathrm{HCl}$ exposure and four hours thereafter). (Filled symbols: butyrate incubation, open symbols: control experiment; $\%$ iv = per cent of initial value at 0 hours).

TABLE II Effect of n-butyrate on colonic mucosa after $\mathrm{HCl}$ induced injury

\begin{tabular}{|c|c|c|c|}
\hline & Butyrate & $\mathrm{NaCl}$ (control) & p Value \\
\hline \multicolumn{4}{|c|}{$\begin{array}{l}\text { (A) Effect of butyrate }(20 \mathrm{mmol})(n=6) \text { added to the luminal side of the mucosal without a } \\
\text { preincubation period }\end{array}$} \\
\hline $\begin{array}{l}\text { Potential difference (AUC: } \% \text { iv } \times \mathrm{h} \text { ) } \\
\text { Conductance (AUC: } \% \text { iv } \times \mathrm{h} \text { ) } \\
\text { Mannitol }_{\mathrm{s}} \text { (AUC: } \mu \mathrm{mol} / / \times \mathrm{h} \text { ) } \\
\text { Lactulose }_{\mathrm{s}}(\mathrm{AUC}: \mu \mathrm{mol} / / \times \mathrm{h} \text { ) } \\
\text { EPEC }_{\mathrm{s}}(\mathrm{cfu} / \mathrm{ml}) \text { } 4 \mathrm{~h}\end{array}$ & $\begin{array}{l}250 \cdot 8+67 \cdot 8 \\
535 \cdot 3+41 \cdot 7 \\
204 \cdot 8+32 \cdot 1 \\
277 \cdot 5+114 \cdot 2 \\
3234+2954\end{array}$ & $\begin{array}{l}321 \cdot 0+85 \cdot 7 \\
495 \cdot 2+15 \cdot 6 \\
177 \cdot 3+35 \cdot 3 \\
162 \cdot 0+35 \cdot 4 \\
3563+1173\end{array}$ & $\begin{array}{l}\text { NS } \\
\text { NS } \\
\text { NS } \\
\text { NS } \\
\text { NS }\end{array}$ \\
\hline $\begin{array}{l}\text { Mucosal cell proliferation: total } \\
\text { crypt labelling index } 4 \mathrm{~h}\end{array}$ & $0 \cdot 13+0 \cdot 01$ & $0 \cdot 11+0 \cdot 01$ & NS \\
\hline \multicolumn{4}{|c|}{$\begin{array}{l}\text { (B) Effect of butyrate }(20 \text { mmoll) }(n=7) \text { added to the luminal side of the mucosa with a preincubation } \\
\text { period (one hour before } \mathrm{HCl} \text { exposure and four hours thereafier) }\end{array}$} \\
\hline $\begin{array}{l}\text { Potential difference (AUC: } \% \text { iv } \times \text { h) } \\
\text { Conductance (AUC: } \% \text { iv } \times \mathrm{h} \text { ) } \\
\text { Mannitol }_{\mathrm{s}} \text { (AUC: } \mu \mathrm{mol} / / \times \mathrm{h} \text { ) } \\
\text { Lactulose }_{\mathrm{s}}(\mathrm{AUC}: \mu \mathrm{mol} / / \times \mathrm{h} \text { ) } \\
\text { EPEC }_{\mathrm{s}}(\mathrm{cfu} / \mathrm{ml}) \quad \mathbf{4 h}\end{array}$ & $\begin{array}{c}249 \cdot 6+65 \cdot 2 \\
497 \cdot 2+79 \cdot 3 \\
67 \cdot 4+5 \cdot 6 \\
64 \cdot 1+11 \cdot 9 \\
9200+3789\end{array}$ & $\begin{array}{r}282 \cdot 0+49 \cdot 6 \\
532 \cdot 1+89 \cdot 1 \\
84 \cdot 3+14 \cdot 4 \\
73 \cdot 2+17 \cdot 8 \\
25857+19211\end{array}$ & $\begin{array}{l}\text { NS } \\
\text { NS } \\
\text { NS } \\
0 \cdot 028 \\
\text { NS }\end{array}$ \\
\hline $\begin{array}{l}\text { Mucosal cell proliferation: total } \\
\text { crypt labelling index } 4 \mathrm{~h}\end{array}$ & $0 \cdot 15+0 \cdot 003$ & $0 \cdot 16+0 \cdot 01$ & NS \\
\hline
\end{tabular}

Abbreviations as in Table I.
L-glutamine run, conductance rose significantly at one hour, but subsequently returned to the range of the initial value (104-118\%, NS). A significant difference between L-glutamine and control experiment was found at two, three, and four hours. L-glutamine diminished the permeability for mannitol, whereas no significant difference was seen for lactulose (Table IB). EPEC permeation was not different between L-glutamine and control run. Serosal L-glutamine raised the total crypt labelling index significantly.

\section{Butyrate experiments}

The data of butyrate experiments (no preincubation with butyrate before $\mathrm{HCl}$ incubation, $\mathrm{n}=6$ ) are given in Table IIA and Figure 3A. Butyrate added to the luminal side after acid exposure did not affect PD or tissue conductance. The permeability of mannitol and lactulose was similar in butyrate and control experiments. EPEC permeation did not differ between butyrate and control. In this experimental setting, butyrate had no effect on mucosal cell proliferation.

Following on from experimental data of Loucks and Buell ${ }^{12}$ the hypothesis was tested that acid induced tissue damage might be avoided if the mucosa was pretreated with luminal butyrate ( $n=7$, Table IIB, Fig 3B). However, PD and conductance were unchanged by butyrate incubation of the mucosa. Epithelial permeability for saccharides was not different between serum and control experiments. EPEC permeation was unaffected by luminal butyrate. No significant differences were detected for epithelial cell proliferation.

\section{Discussion}

In this section two issues will be discussed: (a) Is the Ussing chamber technique adequate to study the recovery of colonic mucosa after acid induced injury? (b) What are the implications of the positive glutamine and the negative butyrate data?

\section{Experimental injury and restitution of the colonic}

\section{mucosa}

The technique of mounting stripped colonic mucosa in Ussing chambers and measuring post-injury epithelial recovery has been used previously. Feil et al ${ }^{15}$ incubated human colonic specimens obtained at surgery with hydrochloric acid $(10 \mathrm{mmol} / 1$ for $10 \mathrm{~min})$ and observed a $70 \%$ drop of $\mathrm{PD}$, which remained low despite morphological restitution of the epithelium. Tissue conductance was not measured in this experiment. Light microscopy of histological sections showed uniform mucosal damage confined to the superficial layer with the crypts left intact (15 minutes post-injury). After two hours, incipient epithelial restitution was noted by light microscopy. After five hours the necrotic layer had lifted off and the denuded basal lamina was covered with flattened epithelial cells that had migrated from the intact crypts. Electron microscopic 
analysis showed that non-goblet cells projected lamellipodia and migrated over the denuded basal lamina at a speed of $2 \mu \mathrm{m} / \mathrm{min}$. Morphometrically, $96 \%$ of the surface was judged necrotic, whereas after five hours only $17 \%$ of the mucosa remained damaged. In our validation experiment a significant drop of $P D$ was observed and an increase in tissue conductance in the first two hours after injury. Generally, mucosal damage was reflected by a more pronounced change of conductance than PD. Using light microscopy, we found extensive superficial damage one hour and resealing of the mucosa four hours after $\mathrm{HCl}$ (Fig 1A/B). We therefore judged that we could assess possible effects of gut nutrients on epithelial restitution within a time frame of four hours.

Mannitol (diameter: $6.7 \times 10^{-10} \mathrm{~m}$ ) and lactulose (diameter: $9.5 \times 10^{-10} \mathrm{~m}$ ) are well established markers of intestinal para-cellular permeability. ${ }^{24}$ Compared with the small intestine, colonic epithelium is considered to be much tighter, having higher epithelial resistance and lower permeability. However, it has recently been shown that the rat colon is permeable even to inulin, a molecule with a diameter of $15 \times 10^{-10} \mathrm{~m} .{ }^{25}$ Sugars like mannitol and lactulose are, therefore, also suitable markers for colonic permeability measurements. Our validation experiment showed a significantly higher permeability for both markers one and two hours after $\mathrm{HCl}$, compared with control conditions. No difference between mannitol and lactulose was detected. This may be explained by the gross superficial damage cause by $\mathrm{HCl}$, which does not select for pore size. Similar data were obtained by Argenzio et $a l^{11}$ who perfused the porcine colon in vivo with deoxycholate $(15 \mathrm{mmol} / \mathrm{l})$ causing acute mucosal injury similar to that seen in our experiment. This intervention raised the mannitol permeability significantly; however, within 40 minutes mannitol permeability was normalised because of reepithelialisation with flattened cells migrating from the crypts to the flat mucosa.

Bacterial 'translocation' is defined as invasion of bacteria from the gut lumen to mainly sterile body compartments (liver, spleen, mesenteric lymph nodes). This phenomenon has been seen in animal experiments ${ }^{26} 27$ but may also contribute to human perioperative morbidity. ${ }^{28}$ In addition to absorptive and secretory functions the maintenance of the barrier against bacterial entry is an important role of the colonic mucosa. The interaction of enteropathogenic $E$ coli $\mathrm{O} 111: \mathrm{H}^{-}$with rabbit intestinal mucosa has recently been shown in vitro. ${ }^{29}$ Factors that re-establish the morphological and functional integrity of the epithelium may also contribute to the preservation of the barrier function. In our Ussing chamber study, bacterial 'translocation' was not measured in the strict sense of the definition given above; instead, the term 'permeation' was used. It could be shown in the validation experiment that bacterial permeation from the luminal to the serosal side increased significantly after $\mathrm{HCl}$ induced injury, compared with control conditions. Therefore, bacterial permeation was used as another marker of mucosal damage possibly affected by gut nutrients.

As Figure 1A shows, acid induced injury affects the epithelial surface while it leaves the colonic crypts intact. Cell renewal takes its origin within the crypt where proliferation occurs in the basal compartments. Cells migrate to the upper crypt where they stop proliferating and achieve a state of full differentiation. After a life span of about a week, senescent cells become apoptotic and are shed to the lumen. ${ }^{30}$ This process is not disturbed by acid induced injury; the validation experiment of our study showed that luminal $\mathrm{HCl}$ had no effect on cell proliferation in the crypts. It was hypothesised that gut nutrients stimulate cell proliferation, which may be associated with epithelial restitution after injury.

\section{Effects of gut nutrients (glutamine, butyrate)}

L-glutamine is among the most abundant free amino acids in the body and controls many pathways of intermediary metabolism. Windmueller and Spaeth ${ }^{31}$ suggested that glutamine delivered a major portion of the energy required by enterocytes. In colonocytes, similar findings were reported by Ardawi and Newsholme. ${ }^{32}$ By an unknown signal transduction pathway, glutamine also stimulates DNA synthesis of epithelial cells taken from the human ileum, proximal colon, and distal colon. ${ }^{6}$ Assuming an important role of glutamine for the welfare of the colonic mucosa, we studied effects of this amino acid on epithelial recovery after acid induced injury.

As glutamine is readily taken up both by the apical and basolateral membranes ${ }^{33}$ a maximum effect was attempted by adding glutamine to the luminal and serosal sides of the mucosa (Table IA). Glutamine delivered to both sides of the mucosa stimulated DNA synthesis as it was anticipated from previous incubation experiments of human biopsy material. ${ }^{6}$ This proliferative effect was associated with increased functional integrity of the mucosa (conductance, saccharide permeability, EPEC permeation). It is unknown if there is a causal relation between cell proliferation and resealing of the mucosa. Cell migration has been proposed as an alternative mechanism for epithelial restitution; this phenomenon may also be affected by glutamine via unknown pathways.

The data for serosal glutamine (Table IB) were not as clear as for serosal/mucosal glutamine. However, most of the functional parameters were affected (PD, conductance, mannitol permeability). Significant differences were missed for lactulose permeability and EPEC permeation, possibly because of the small sample size. Serosal glutamine had a trophic effect on epithelial cells, as shown by a significantly higher total crypt labelling index. In animal experiments (in vivo) intravenous glutamine has been shown to favour epithelial healing after various forms of injury. ${ }^{34} 35$ If these findings can be reproduced in the clinical setting, glutamine administration may become 
important for patients in the intensive care unit. ${ }^{36}$ The drawback of free glutamine being unstable during heat sterilisation and storage can be overcome by using the stable and highly soluble dipeptide L-alanyl-L-glutamine. At present, such dipeptide solutions are being marketed.

Under the experimental conditions of this study, luminal butyrate did not affect resealing of the mucosa after acid induced injury. The finding of a lower lactulose permeability in the absence of other significant data (Table IIB) is considered a chance finding. Similarly, negative data were obtained when butyrate was added to the luminal chamber only after acid exposure (no preincubation period) or before and after $\mathrm{HCl}$ exposure (butyrate preincubation). This last experiment was performed as Loucks and Buell ${ }^{11}$ have described a protective effect of butyrate when a preincubation was performed before exposure to a 'barrier breaker' (ethanol). In their study the clearance of ${ }^{51} \mathrm{Cr}$-EDTA from blood to lumen was assessed as a marker of microvascular and epithelial permeability, which was significantly reduced in the presence of luminal butyrate $(20 \mathrm{mmol} / \mathrm{l})$. It cannot be excluded that the choice of the agent that causes epithelial damage ( $\mathrm{HCl} v$ ethanol) has an impact on results. When monolayers of $\mathrm{CaCo}-2$ colon carcinoma cells were studied ${ }^{37}$ butyrate $(2 \mathrm{mmol} / \mathrm{l})$ reduced paracellular permeability (increased transepithelial resistance, and reduced mannitol flux). Butyrate also improved wound healing of IEC-6 enterocyte monolayers after injury with a razor blade. ${ }^{38}$ In a rat model, infusion of short chain fatty acids into the proximal colon accelerated the healing of distal colonic anastomosis. ${ }^{39}$ In view of these data, our negative results are disappointing. However, there is another negative study in which effects of butyrate were tested in the Ussing chamber. ${ }^{40}$ Mucosa taken from distal rat colon was exposed to luminal deoxycholate until the electrical resistance fell by $50 \%$. Luminal butyrate $(25 \mathrm{mmol} / \mathrm{l})$ did not influence epithelial recovery (PD, resistance) monitored for five hours after injury. This experimental set up was closest to our procedure and yielded similar data.

In our previous experiments ${ }^{5}$ butyrate stimulated mucosal proliferation in biopsy specimens taken from the human caecum. Other authors ${ }^{41} 42$ have shown this effect in the rat colon (in vivo). It was surprising that butyrate had no effect on DNA synthesis of isolated mucosa placed in Ussing chambers. An explanation for this discrepancy may be that a cell culture medium (containing fetal calf serum) was used in the biopsy studies, ${ }^{5}$ whereas an electrolyte solution was used in the Ussing chamber experiments. It may be that butyrate can stimulate mucosal DNA synthesis only in the presence of a nitrogen source. Glutamine, in contrast, carries two $\mathrm{N}$ atoms itself. In addition to providing $\mathrm{N}$, a cell culture medium contains a range of growth factors ${ }^{43}$ whose presence may be necessary before butyrate can induce cell proliferation.

The $\mathrm{pH}$ value of the bathing solutions (luminal and serosal) was 7.55 in this experiment. It is known that the colonic luminal $\mathrm{pH}$ may be as low as 5.5 when there is active fermentation (proximal colon). ${ }^{44}$ It can be speculated that the action of butyrate would have been different in a more acid environment. The amount of butyrate in an un-ionised form may be critical to its action in the colon ( $\mathrm{pK}$ value of butyrate $4 \cdot 81$ ).

In conclusion, stripped colonic mucosa placed in Ussing chambers can be used to study epithelial injury and repair in vitro. Under the conditions chosen in this study, glutamine did and butyrate did not affect mucosal resealing after $\mathrm{HCl}$ induced injury. The molecular mechanisms underlying the effects of luminal nutrients are unknown. However, it has recently been shown in IEC- 6 cells that glutamine activates mitogen activated protein kinases, c-Jun nuclear kinases, and activating protein-1 dependent gene transcription; it also increases the effect of epidermal and insulinlike growth factors on DNA synthesis and may thereby facilitate intestinal repair. ${ }^{45}$

We thank H DeJonge, PhD (Rotterdam) and G Rechkemmer, $\mathrm{PhD}$ (Hanover) for valuable advice concerning the Ussing chamber technique. The expert technical assistance of $\mathbf{B}$ Plaschke, A Weimer, and E Liebscher is gratefully acknowledged.

This work was presented in abstract form (Gastroenterology 1995; 108: A752) at the 95th Annual Meeting of the American Gastroenterological Association, San Diego, 17 May 1995.

1 Roediger WEW. Metabolic basis of starvation diarrhoea: implications for treatment. Lancet 1986; i: 1082-4.

2 Janne $P$, Carpentier Y, Willems G. Colonic mucosal atrophy induced by a liquid elemental diet in rats. Dig Dis 1977; 22: 808-12.

3 Maxton DG, Cynk EU, Thompson RPH. Small intestinal response to 'elemental' and 'complete' liquid feeds in the rat: effect of dietary bulk. Gut 1987; 28: 688-93.

4 Roediger WEW. Role of anaerobic bacteria in the metabolic welfare of the colonic mucosa. Gut 1980; 21: 793-8.

5 Scheppach W, Bartram P, Richter A, Richter F, Liepold H, Dusel G, et al. Effect of short-chain fatty acids on the human colonic mucosal in vitro. 7 Parenter Enteral Nutr 1992; 16: 43-8.

6 Scheppach W, Loges C, Bartram P, Christl SU, Richter F, Dusel $\mathrm{G}$, et al. Effect of free glutamine and alanyl-glutamine dipeptide on mucosal proliferation of the human mine dipeptide on mucosal proliferation of the hum

7 Roediger WEW. The starved colon - diminished mucosal nutrition, diminished absorption, and colitis. Dis Colon Rectum 1990; 33: 858-62.

8 Wischmeyer P, Pemberton JH, Phillips SF. Chronic pouchitis after ileal pouch-anal anastomosis: responses to butyrate and glutamine suppositories in a pilot study. Mayo Clin Proc 1993; 68: 978-81.

9 Steinhart AH, Brzezinski A, Baker JP. Treatment of refractory ulcerative proctosigmoiditis with butyrate enemas. Am $f$ Gastroenterol 1994; 89: 179-83.

10 Scheppach W, Sommer H, Kirchner T, Paganelli G-M, Bartram P, Christl S, et al. Effect of butyrate enemas on the colonic mucosa in distal ulcerative colitis. Gastroenterology 1992; 103: 51-6.

11 Argenzio RA, Henrikson CK, Liacos JA. Restitution of barrier and transport function of porcine colon after acute mucosal injury. Am $\mathcal{F}$ Physiol 1988; 255: G62-71.

12 Loucks DC, Buell MG. The differing protective effect of short chain fatty acids on ethanol-induced colonic mucosal injury. Gastroenterology 1994; 106: A1036.

13 Cohen JD, Kao HW, Tan ST, Lechago J, Snape WJ. Effect of acute experimental colitis on rabbit colonic smooth muscle. Am f Physiol 1986; 251: G538-45.

14 Argenzio RA, Meuten DJ. Short-chain fatty acids induce reversible injury of porcine colon. Dig Dis Sci 1991; 36: 1459-68.

15 Feil W, Lacy ER, Wong YM, Burger D, Wenzl E, Starlinger $M$, et al. Rapid epithelial restitution of human and rabbi colonic mucosa. Gastroenterology 1989; 97: 685-701.

16 Engelhardt $W$, Burmester $M$, Hansen $K$, Becker $G$, Rechkemmer G. Effects of amiloride and ouabain on short-chain fatty acid transport in guinea-pig large intestine. F Physiol 1993; 460: 455-66.

17 Field M, Fromm D, McColl I. Ion transport in rabbit ileal mucosa. I. $\mathrm{Na}$ and $\mathrm{Cl}$ fluxes and short-circuit current. $\mathrm{Am}$ f Physiol 1971; 220: 1388-96.

18 O'Grady SM, DeJonge HR, Vaandrager AB, Field M. Cyclic nucleotide-dependent protein kinase inhibition by $\mathrm{H}-8$ : effects on ion transport. Am $\mathcal{F}$ Physiol 1988; 254: C115-21.

19 Shippee RL, Johnson AA, Cioff WG, Lasko J, LeVoyer T, Jordan BS. Simultaneous determination of lactulose and mannitol in urine of burn patients by gas-liquid chromatography. Clin Chem 1992; 38: 343-5. 
20 Franke J, Franke S, Schmidt H, Schwarzkopf A, Wieler LH, Baljer G, et al. Nucleotide sequence analysis of enteropathogenic Escherichia coli (EPEC) adherence factor probe and development of PCR for rapid detection of EPEC harboring virulence plasmids. 7 Clin Microbiol of EPEC harboring

21 Bartram H-P, Scheppach W, Schmid H, Hofmann A, Dusel $\mathrm{G}$, Richter F, et al. Proliferation of human colonic mucosa as an intermediate biomarker of carcinogenesis: effects of butyrate, deoxycholate, calcium, ammonia, and $\mathrm{pH}$ Cancer Res 1993; 53: 3283-8.

22 Lipkin M, Blattner WE, Fraumeni JF, Lynch HT, Deschner $\mathrm{E}$, Winawer S. Tritiated thymidine (øp,øh) labeling distribution as a marker for hereditary predisposition to colon cancer. Cancer Res 1983; 43: 1899-904.

23 Moore R, Madri J, Carson S, Madara JL. Collagens facilitate epithelial migration in restitution of native guinea pig

24 Bjarnason I, MacPherson A, Hollander D. Intestinal permeability: an overview. Gastroenterology 1995; 108 1566-81.

25 Ma TY, Hollander D, Erickson RA, Truong H, Nguyen $H$ Krugliak P. Mechanism of colonic permeation of inulin: is rat colon more permeable than small intestine? Gastroenterology 1995; 108: 12-20.

26 Deitch EA, Winterton J, Berg R. The gut as a portal of entry for bacteremia. Ann Surg 1987; 205: 681-92.

27 Wilmore DW, Smith RI, O'Dwyer ST, Jacobs DO, Ziegler TR, Wang X-D. The gut: a central organ after surgical stress. Surgery 1988; 104: 917-23.

28 Sedman PC, Macfie J, Sagar P, Mitchell CJ, May J Mancey-Jones B, et al. The prevalence of gut translocation Mancey-Jones B, et al. The prevalence of gut tran
in humans. Gastroenterology 1994; 107: 643-9.

29 Embaye H, Batt RM, Saunders JR, Getty B, Hart CA Interaction of enteropathogenic Escherichia coli 0111 with rabbit intestinal mucosa in vitro. Gastroenterology 1989; 96: 1079-86.

30 Wright N. The biology of epithelial cell populations. Vol 2. Oxford: Claredon, 1984

31 Windmueller HG, Spaeth AE. Identification of ketone bodies and glutamine as the major respiratory fuels in vivo for postabsorptive rat small intestine. 7 Biol Chem 1978 , 253: 69-76.

32 Ardawi MSM, Newsholme EA. Fuel utilization in colonocytes of the rat. Biochem $\mathcal{F} 1985 ; 231: 713-9$.

33 Windmueller $H$ Spaeth AE. Intestinal metabolism of glutamine and glutamate from the lumen as compared to glutamine from blood. Arch Biochem Biophys 1975; 171: 662-72.

34 Fox AD, Kripke SA, DePaula J, Berman JM, Settle RG Rombeau JL. Effect of a glutamine-supplemented enteral diet on methotrexate-induced enterocolitis. $₹$ Parenter diet on methotrexate-induced
Enteral Nutr 1988; 12: 325-31.

35 Souba WW, Klimberg VS, Hautamaki RD, Mendenhal WH, Bova FC, Howard RJ, et al. Oral glutamine reduces bacterial translocation following abdominal radiation. f Surg Res 1990; 48: 1-5.

36 Tremel H, Kienle B, Weilemann LS, Stehle P, Fuerst P. Glutamine dipeptide-supplemented parenteral nutrition maintains intestinal function in the critically ill. Gastroenterology 1994; 107: 1595-601.

37 Mariadson JM, Gibson PR. The effect of butyrate on paracellular permeability in the $\mathrm{CaCo}-2$ model of colonic epithelium. Gastroenterology 1994; 106: A729.

38 Weng V, Purtic B, Smith T, Emerson R, Harmatz P. The effect of short chain fatty acids on intestinal wound healing. Gastroenterology 1995; 108: A763.

39 Rolandelli RH, Koruda MJ, Settle RG, Rombeau JL Effects of intraluminal short-chain fatty acids on the healing of colonic anastomosis in the rat. Surgery 1986; 100: 189-203.

40 Prasad M, Goddard PJ, Carter KJ, Milbank AJ, Silen W. In vitro restitution in rat colon: effects of butyrate and bicarbonate. Gastroenterology 1993; 104: A272.

41 Kripke SA, Fox AD, Berman JM, Settle RG, Rombeau JL. Stimulation of intestinal mucosal growth with intracolonic infusion of short-chain fatty acids. ₹ Parenter Enteral Nutr 1989; 13: 109-16.

42 Sakata T. Stimulatory effect of short-chain fatty acids on epithelial cell proliferation in the rat intestine: a possible explanation for trophic effects of fermentable fibre, gut microbes and luminal trophic factors. Br f Nutr 1987; 58: 95-103.

43 Dignass AU, Podolsky DK. Cytokine modulation of intestinal epithelial cell restitution: central role of transforming growth factor $\beta$. Gastroenterology 1993; 105: 1323-32.

44 Cummings JH, Pomare EW, Branch WJ, Naylor CPE, Macfarlane GT. Short chain fatty acids in human large 1221-7.

45 Rhoads JM, Chen W, Rippe RA, Westwick JK, Argenzio $\mathrm{RA}$, Guan X, et al. Glutamine (GLN) stimulates enterocyte proliferation by activating early response genes. Gastroenterology 1995; 108: A749. 